\title{
Effect of gelatin-based active coatings formulated with rosemary extract on quality of cold stored meatballs
}

\author{
Gülşen Berat TORUSDAĞ ${ }^{1}$, Sümeyra GÜMÜŞ², Gökhan BORAN
}

\begin{abstract}
Meatballs were coated by gelatin-based mixes incorporated with potassium sorbate and rosemary extract. Coated samples were evaluated by free fatty acids (FFAs), thiobarbituric acid reactive substances (TBARS), and total volatile basic nitrogen (TVB-N) content. In addition, texture profile analysis (TPA) was performed to evaluate the textural features of meatballs. Uncoated sample as control along with 3 other samples coated by different formulations were stored in zipped plastic bags at $+4{ }^{\circ} \mathrm{C}$ for 10 days. No significant difference was observed between samples regarding FFA and TBARS although coating with potassium sorbate showed suppressive effect on TVB-N initially. The starting $\mathrm{pH}$ of meatball was 6.22 and the coatings generally limited the change in $\mathrm{pH}$ compared to the control. Although significant differences in color were observed due to the color of coating itself, the coatings limited the variations in color to some extent. Other quality parameters were not improved much with the studied formulations. It is concluded that active edible coatings might be utilized in muscle foods for preservation and shelf-life extension if appropriately formulated and applied. Comprehensive studies are needed to determine the performance of carrier polymers in release of active ingredients and suitable formulations for every single group of food.
\end{abstract}

Keywords: edible coating; gelatin; meatball; potassium sorbate; rosemary; quality.

Practical Application: The presented work concludes that edible and active coatings may successfully be used in preservation of muscle foods. However, further studies are needed to optimize such formulations for superior release of active ingredients and also, for better preservation of the quality. Nevertheless, meat and seafood processing industry may find the data presented in this study useful and utilize edible and active coatings for shelf-life extension and/or for improving the nutritional and bioactive value of such products.

\section{Introduction}

Consumer demand has recently focused on healthy and bio-functional food although food safety and quality has always been an issue. There are many new methods currently under investigation to extend the shelf life and to preserve the foods with minimal processing. Keeping that in mind, edible coatings have gained some attention because of their potential use of carrying functional ingredients as well as active agents for creating healthy and bio-functional food formulations along with extended food quality (Aloui \& Khwaldia, 2016; Díaz-Montes \& Castro-Muñoz, 2021).

Nowadays, due to the increasing demand of consumers for safe products and the need to reduce food consumption, there has been an increase in the search for biodegradable packaging technologies that help reduce the negative impact of conventional packaging materials on the environment. In this context, the widespread use of edible films is particularly interesting (Fabra et al., 2018; Bojorges et al., 2020). Edible films can be used to protect food products by creating a "skin" on the products to protect them from microorganisms, chemicals or many different contamination sources available in the surrounding environment. Such films can mechanically protect food products, prevent the loss of water, volatile and flavor components, as well as reduce the level of food spoilage by controlling the passage of moisture, oxygen, and oxidizing agents (Kester \& Fennema, 1989; Xie et al., 2002; Bravin et al., 2006). In addition, edible films are increasingly attracted because of their potential to improve sensory properties by providing a brighter and smoother appearance on the surface (Bravin et al., 2006).

Gelatin is an additive generally used as a thickening agent in the food industry. Its transparent, colorless, odorless and easily melting gel structure has not yet been achieved by other thickeners (Boran, 2011). Gelatin is also widely used in molecular gastronomy applications as a gelling ingredient as one of the rapidly spreading culinary trends (Ivanovic et al., 2011; Özdemir \& Altıner, 2018). Gelatin-based edible coatings are materials in which gelatin is used as a carrier polymer and its mechanical strength is increased with the use of various plasticizers. The functional, organoleptic, nutritional and mechanical properties of gelatin-based edible coatings can be improved with various materials used in its production (Topuz \& Boran, 2018). Compared to carbohydrate-based thickeners, 
gelatin has significant advantages in some aspects and is widely preferred due to its functional and technological advantages.

Meat has been an essential part of human diet since prehistoric times. In addition, it has a significant place among foods of animal origin in terms of nutritional value. Red meat is vital for mental and physical development due to its high protein content, not because of the quantity but quality i.e., it is rich and adequate in essential amino acids along with its high content of vitamin and minerals (Umaraw et al., 2020). Being highly sensitive to oxidation and various products including aldehydes, ketones, alcohols and other toxic compounds formed during oxidation may significantly limit the quality of meat and meat products. Meat is also very sensitive to microbiological deterioration and its shelf life is relatively short under inappropriate conditions (Bolumar et al., 2021). Post-mortem changes adversely affect quality parameters such as texture, color and taste, which reduce the shelf life and nutritional value of meat products. These problems, which pose a risk for consumers, also cause economic losses for producers (Bojorges et al., 2020). Edible films and/or coatings may conceptually help with preserving the composition and the nutritional value of meat, preventing moisture loss and transmission of volatiles; adding functionality to meat products, stabilizing the color and texture, reducing lipid oxidation, and extending the shelf life (Umaraw et al., 2020).

The use of edible films carrying antimicrobial and antioxidant ingredients is an active form of packaging that may contribute to shelf-life extension of food products and reduced safety risks for consumers. Organic acids, enzymes, fungicides, natural antimicrobial and antioxidant components are included in edible films for this purpose. Potassium sorbate (PS) is an antimicrobial food preservative that has been widely used for many years to stop or slow the growth of food pathogens and is generally considered as safe (Pranoto et al., 2005; Shen et al., 2010). Rosemary (Rosmarinus officinalis) is used as a natural preservative in foods due to its high antioxidant activity. The ingredients "1,8-cineol, a-pinene, camphor, camphor, borneol, piperitone, linalo" are the main components of rosemary essential oil. The antioxidant and antimicrobial effects of these main components have been reported by previous studies (Duman et al., 2012; Vital et al., 2016, 2018; Choulitoudi et al., 2017).

In this study, the effect of active coatings formulated with gelatin as a carrier polymer, sorbitol and glycerol as plasticizers, potassium sorbate as antimicrobial agent and rosemary extract as antioxidant ingredient on meatballs were investigated during cold storage at $4{ }^{\circ} \mathrm{C}$ for 10 days by following some chemical quality parameters and textural features during the storage. It was aimed to demonstrate that active coatings may be an appropriate method to ensure the quality and safety of meatballs sold as ready-to-use in markets and butchers.

\section{Materials and methods}

\subsection{Materials}

Minced beef meat and spices used for meatball mix were obtained from local markets. Bovine gelatin, potassium sorbate, glycerol, sorbitol and rosemary powder were obtained from local suppliers and of food grade. All ingredients were brought to the laboratory and the meatball dough was prepared as briefly described. Minced beef meat, as obtained from the butcher, was mixed with salt, onion, garlic, olive oil, egg, water and other spices. Formulation of meatball mix was $1500 \mathrm{~g}$ of minced meat (beef), $500 \mathrm{~g}$ of bread crumbs, $250 \mathrm{~g}$ of onion, $145 \mathrm{~g}$ of egg, $10 \mathrm{~g}$ of garlic, $30 \mathrm{~g}$ of olive oil, $10 \mathrm{~g}$ of salt, $5 \mathrm{~g}$ of red pepper flakes, $2 \mathrm{~g}$ of cumin and $2 \mathrm{~g}$ of black pepper. After kneading the mix, it was left to rest in the refrigerator for an hour. Then, the mix was portioned by hand in ice cube molds to shape. The flow chart of meatball production is given in Figure 1.

\subsection{Sample preparation}

The prepared meatballs were covered with active coating solutions by spraying. Meatballs were divided into 4 different groups including the control (uncoated) and 3 other samples coated by different coating formulations. Then, all 4 group of samples were placed in zipped bags and kept in the refrigerator at $4{ }^{\circ} \mathrm{C}$ for 10 days. All measurements were periodically performed at the beginning and on the 1st, $2 \mathrm{nd}, 3 \mathrm{rd}$, 7 th and 10th days of storage. All chemicals used were of analytical grade and obtained from Sigma-Aldrich (Missouri, USA) and Merck (Darmstadt, Germany). Formulation of edible coatings was composed of bovine gelatin $(\mathrm{Gel})$ as carrier polymer; both sorbitol (Sor) and glycerol (Gly) as plasticizers; potassium sorbate (PS) and rosemary extract (RE) as antimicrobial and antioxidant agent, respectively. Stock solutions used in coating formulations are given below:

Stc.1: $100 \mathrm{~g}$ of gelatin, $20 \mathrm{~g}$ of sorbitol, $10 \mathrm{~mL}$ of glycerol completed to $1 \mathrm{~L}$ by distilled water.

Stc.2: $50 \mathrm{~g}$ of potassium sorbate completed to $500 \mathrm{~mL}$ by distilled water.

Stc.3: $25 \mathrm{~g}$ of rosemary powder completed to $250 \mathrm{~mL}$ by distilled water. This mix was kept in a water bath at $50{ }^{\circ} \mathrm{C}$ for an hour with occasional stirring. Then, the mix was filtered through 4 layers of cheese cloth. This filtrate (about $200 \mathrm{~mL}$ ) was completed to $250 \mathrm{~mL}$ by distilled water.

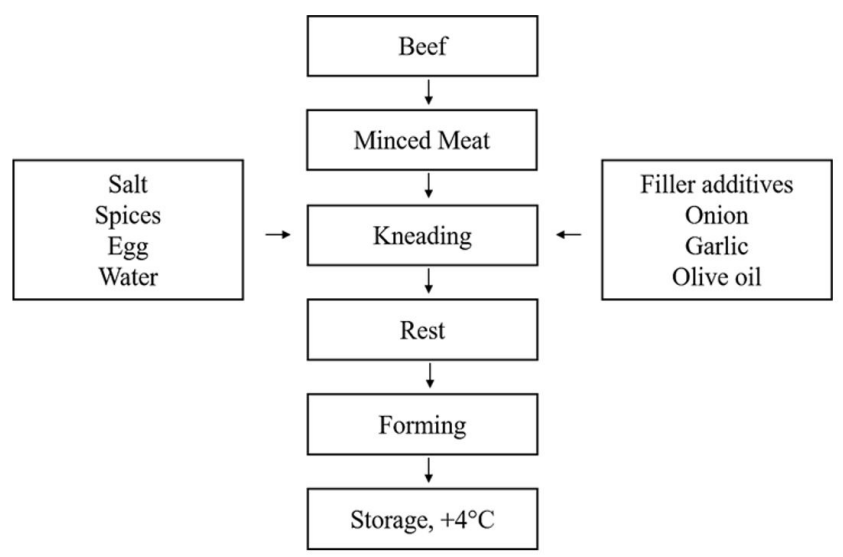

Figure 1. Flowchart of meatball production. 
Coating solutions were obtained by different combinations of Stc.1, Stc.2 and Stc.3 solutions. Coating formulations and corresponding coding of the samples are given below:

C (Control): No coating.

PS: $100 \mathrm{~mL}$ of Stc. $1+50 \mathrm{~mL}$ of Stc. $2+50 \mathrm{~mL}$ of distilled water.

RE25: $100 \mathrm{~mL}$ of Stc. $1+50 \mathrm{~mL}$ of Stc. $2+25 \mathrm{~mL}$ of Stc. $3+$ $25 \mathrm{~mL}$ of distilled water.

RE50: $100 \mathrm{~mL}$ of Stc. $1+50 \mathrm{~mL}$ of Stc. $2+50 \mathrm{~mL}$ of Stc. 3 .

\subsection{Methods}

\section{pH measurement}

For measurement of $\mathrm{pH}, 2 \mathrm{~g}$ of homogenized meatball sample was mixed by $20 \mathrm{~mL}$ of distilled water. Then, $\mathrm{pH}$ value was measured using a $\mathrm{pH}$ meter (SG7, Mettler Toledo, OH, USA) (Soares et al., 2013).

\section{Color analysis}

Color parameters of $\mathrm{L}$, $\mathrm{a}$, and $\mathrm{b}$ were determined by a portable colorimeter (CSM5, PCE Instruments, Southampton Hampshire, UK). Measurements were performed on 5 different points of the surface (Chinnaswamy \& Hanna, 1988). The change of the color in reference to the starting values before the storage was expressed as $\Delta \mathrm{E}$ value and calculated according to the Formula 1 given below.

$$
\Delta E=\sqrt{(L 1-L 2)^{2}+(a 1-a 2)^{2}+(b 1-b 2)^{2}}
$$

\section{Free fatty acids}

Meatball samples were homogenized by a disperser (T18 Ultra-Turrax, IKA, Germany) at ambient temperature in the presence of $\mathrm{n}$-hexane at a ratio of $1: 2(\mathrm{w} / \mathrm{v})$. Then, the mix was filtrated through a coarse filter paper and the solvent was removed by a rotary evaporator. Approximately $0.5 \mathrm{~g}$ of oil sample was weighed and $25 \mathrm{~mL}$ of diethyl ether:ethanol $(1: 1, \mathrm{v} / \mathrm{v})$ was added to dissolve the oil. 2-3 drops of $1 \%$ phenolphthalein indicator were added on this mix. Then, neutralization was achieved by titration by ethanolic solution of $0.1 \mathrm{M}$ potassium hydroxide until a permanent pink color was observed. The amount of free fatty acids (FFAs) was calculated as oleic acid according to the Formula 2 given below (American Oil Chemists Society, 1989).

$$
\text { FFAs }(\% \text { oleic acid })=[(V-S) \times 2.805] / W
$$

$\mathrm{V}: 0.1 \mathrm{M} \mathrm{KOH}$ used in titration of the sample $(\mathrm{mL})$

S: $0.1 \mathrm{M} \mathrm{KOH}$ used in titration of the blind $(\mathrm{mL})$

$\mathrm{W}$ : The amount of oil sample (g)

Conversion factor: 2.805

\section{Total volatile basic nitrogen}

Total volatile basic nitrogen (TVB-N) analysis was performed according to Olgunoğlu (2007). About $10 \mathrm{~g}$ of homogenized meatball sample was weighed into the kjeldahl tube. After adding $1 \mathrm{~g}$ of $\mathrm{MgO}$ and $100 \mathrm{~mL}$ of distilled water, it was placed in the distillation apparatus. $10 \mathrm{~mL}$ of $3 \%$ boric acid, 8 drops of methyl red and $100 \mathrm{~mL}$ of distilled water were added to the flask into where the distillate was collected. The instrument was operated until there was approximately $200 \mathrm{~mL}$ of distillate. The collected distillate was titrated with $0.1 \mathrm{~N} \mathrm{HCl}$ and the consumption was recorded. TVB-N value was calculated according to the Formula 3 given below.

$T V B-N(m g$ of $T V B-N$ in $100 g$ sample $)=(V \times 1.4 \times 100) / W(3)$

$\mathrm{V}$ : The amount of $0.1 \mathrm{~N} \mathrm{NaOH}$ used in titration $(\mathrm{mL})$

$\mathrm{W}$ : The amount of the sample (g)

\section{Thiobarbituric acid reactive substances}

About $10 \mathrm{~g}$ of homogenized meatball sample was transferred into kjeldahl tubes and then $97.5 \mathrm{~mL}$ of distilled water and $2.5 \mathrm{~mL}$ of $4 \mathrm{~N} \mathrm{HCl}$ solution were added to the tubes. Glass beads were added to prevent foaming during distillation. Distillation was continued until approximately $200 \mathrm{~mL}$ of distillate was obtained. $5 \mathrm{~mL}$ of the obtained distillate was transferred to a glass-capped test tube and $5 \mathrm{~mL}$ of $0.02 \mathrm{M}$ TBA reagent was added. Mixing was performed by capping the tube and using a vortex. For the blank, $5 \mathrm{~mL}$ of TBA reagent and $5 \mathrm{~mL}$ of distilled water were added to another test tube and passed through the same process. These mixtures prepared in tubes were kept in a boiling water bath for 35 minutes, left to cool, and the absorbance was determined at a wavelength of $538 \mathrm{~nm}$ using a spectrophotometer. The amount of thiobarbituric acid reactive substances (TBARS) is calculated according to Formula 4 given below (Tarladgis et al., 1960).

TBARS $($ mg malonaldehydes in $100 \mathrm{~g}$ sample $)=$ Absorbance $\times 7.8$

\section{Texture profile analysis}

Texture Profile Analysis (TPA) was performed by using a texture analyzer (TA-XT II, Texture Technologies, USA) with a $125 \mathrm{~mm}$ diameter flat-surface cylindrical head. Meatball samples were prepared in $2 \times 2 \times 2 \mathrm{~cm}$ cubes and a TPA graph was obtained by applying $30 \%(6 \mathrm{~mm})$ compression in both compression cycles. The compression speed was $1 \mathrm{~mm} / \mathrm{s}$, and the movement speed before and after the test was $2 \mathrm{~mm} / \mathrm{s}$. TPA parameters such as hardness, adhesiveness and springiness were calculated from the TPA graph obtained (Bourne, 2002).

\subsection{Statistical analysis}

The raw data obtained were organized as mean \pm standard deviation of at least triplicate measurements. One-way ANOVA was utilized to determine if there is a significant difference between the means. Duncan test was used to determine which pairs are significantly different at a $95 \%$ confidence limit using SPSS program (SPSS Statistic 20, IBM, USA).

\section{Results and discussion}

\subsection{Physical parameters}

Change in $\mathrm{pH}$ values of coated samples is shown in Table 1. The initial $\mathrm{pH}$ of the sample was $6.22 \pm 0.01$. The $\mathrm{pH}$ of the control peaked on the 3 rd day of storage but started to decrease 
Table 1. Change in color and $\mathrm{pH}$ of coated meatballs during storage.

\begin{tabular}{|c|c|c|c|c|c|c|c|}
\hline Parameter & Sample & Initial & Day 1 & Day 2 & Day 3 & Day 7 & Day 10 \\
\hline \multirow[t]{4}{*}{$\mathrm{L}$} & $\mathrm{C}$ & $48.50 \pm 0.90^{\mathrm{Bab}}$ & $49.98 \pm 1.29^{\mathrm{Cb}}$ & $49.31 \pm 1.18^{\mathrm{Bab}}$ & $46.01 \pm 1.77^{\mathrm{Ba}}$ & $49.31 \pm 1.26^{\mathrm{Bab}}$ & $48.83 \pm 1.03^{\mathrm{Aab}}$ \\
\hline & PS & $47.04 \pm 0.71^{\mathrm{ABa}}$ & $47.94 \pm 1.24^{\mathrm{BCa}}$ & $46.90 \pm 1.79^{\mathrm{ABa}}$ & $43.56 \pm 1.68^{\mathrm{Aa}}$ & $46.84 \pm 1.82^{\mathrm{ABa}}$ & $46.53 \pm 1.66^{\mathrm{Aa}}$ \\
\hline & RE25 & $47.91 \pm 1.15^{\mathrm{Ba}}$ & $42.86 \pm 1.89^{\mathrm{Aa}}$ & $45.91 \pm 1.43^{\mathrm{ABa}}$ & $43.60 \pm 1.79^{\mathrm{Aa}}$ & $48.48 \pm 1.64^{\mathrm{Ba}}$ & $46.75 \pm 1.72^{\mathrm{Aa}}$ \\
\hline & RE50 & $45.51 \pm 1.93^{\mathrm{Aa}}$ & $45.24 \pm 1.32^{\mathrm{ABa}}$ & $42.71 \pm 1.81^{\mathrm{Aa}}$ & $43.24 \pm 1.74^{\mathrm{Aa}}$ & $40.82 \pm 1.99^{\mathrm{Aa}}$ & $44.09 \pm 1.55^{\mathrm{Aa}}$ \\
\hline \multirow[t]{4}{*}{$\mathrm{a}$} & $\mathrm{C}$ & $10.26 \pm 1.23^{\mathrm{Aab}}$ & $8.77 \pm 1.91^{\mathrm{Aa}}$ & $9.99 \pm 1.21^{\mathrm{Aab}}$ & $11.36 \pm 0.47^{\mathrm{Abc}}$ & $12.56 \pm 1.41^{\mathrm{ABC}}$ & $13.04 \pm 0.18^{\mathrm{Ac}}$ \\
\hline & PS & $9.91 \pm 1.06^{\mathrm{Aab}}$ & $8.12 \pm 1.63^{\mathrm{Aa}}$ & $10.67 \pm 0.81^{\mathrm{Ab}}$ & $11.45 \pm 0.60^{\mathrm{Ab}}$ & $11.08 \pm 0.64^{\mathrm{Ab}}$ & $12.15 \pm 0.85^{\mathrm{Ab}}$ \\
\hline & RE25 & $12.11 \pm 1.17^{\mathrm{Aa}}$ & $9.08 \pm 1.74^{\mathrm{Aa}}$ & $10.06 \pm 1.32^{\mathrm{Aa}}$ & $10.14 \pm 1.77^{\text {Аа }}$ & $11.29 \pm 0.86^{\mathrm{Aa}}$ & $12.76 \pm 0.93^{\mathrm{Aa}}$ \\
\hline & RE50 & $9.94 \pm 0.91^{\mathrm{Aab}}$ & $9.56 \pm 1.04^{\mathrm{Aa}}$ & $11.28 \pm 0.89^{\mathrm{Ab}}$ & $10.68 \pm 1.08^{\mathrm{Aab}}$ & $13.21 \pm 1.05^{\mathrm{Bc}}$ & $13.43 \pm 0.47^{\mathrm{Ac}}$ \\
\hline \multirow[t]{4}{*}{$\mathrm{b}$} & $\mathrm{C}$ & $25.56 \pm 1.93^{\mathrm{Aa}}$ & $21.26 \pm 1.39^{\mathrm{Aa}}$ & $24.13 \pm 1.59^{\mathrm{Aa}}$ & $25.79 \pm 1.21^{\mathrm{Aa}}$ & $26.05 \pm 1.13^{\mathrm{Aa}}$ & $25.50 \pm 1.10^{\mathrm{Aa}}$ \\
\hline & PS & $25.67 \pm 1.80^{\mathrm{Aa}}$ & $24.65 \pm 0.95^{\mathrm{Aa}}$ & $28.55 \pm 1.54^{\mathrm{Ba}}$ & $27.49 \pm 1.02^{\mathrm{Aa}}$ & $25.61 \pm 1.33^{\mathrm{Aa}}$ & $27.85 \pm 1.29^{\mathrm{Aa}}$ \\
\hline & RE25 & $26.68 \pm 1.86^{\mathrm{Aa}}$ & $22.41 \pm 1.17^{\mathrm{Aa}}$ & $27.69 \pm 1.21^{\mathrm{Ba}}$ & $25.98 \pm 1.54^{\mathrm{Aa}}$ & $25.47 \pm 1.39^{\mathrm{Aa}}$ & $28.12 \pm 1.15^{\mathrm{Aa}}$ \\
\hline & RE50 & $26.47 \pm 1.92^{\mathrm{Aa}}$ & $26.20 \pm 1.23^{\mathrm{Aa}}$ & $28.26 \pm 1.02^{\mathrm{Ba}}$ & $25.00 \pm 1.21^{\mathrm{Aa}}$ & $26.69 \pm 1.60^{\mathrm{Aa}}$ & $27.54 \pm 0.58^{\mathrm{Aa}}$ \\
\hline \multirow[t]{4}{*}{$\Delta \mathrm{E}$} & C & - & $7.18 \pm 1.12^{\mathrm{Aa}}$ & $3.89 \pm 0.43^{\mathrm{Aa}}$ & $4.58 \pm 1.85^{\mathrm{Aa}}$ & $5.09 \pm 1.79^{\mathrm{Aa}}$ & $4.57 \pm 1.95^{\mathrm{Aa}}$ \\
\hline & PS & - & $6.12 \pm 1.90^{\mathrm{Aab}}$ & $3.51 \pm 1.02^{\mathrm{Aa}}$ & $4.42 \pm 1.25^{\mathrm{Aab}}$ & $3.71 \pm 1.86^{\mathrm{Aa}}$ & $7.15 \pm 1.42^{\mathrm{Ab}}$ \\
\hline & RE25 & - & $10.53 \pm 1.22^{\mathrm{Aa}}$ & $6.62 \pm 1.93^{\mathrm{Aa}}$ & $7.51 \pm 1.55^{\mathrm{Aa}}$ & $7.95 \pm 1.31^{\mathrm{Aa}}$ & $6.25 \pm 1.34^{\mathrm{Aa}}$ \\
\hline & RE50 & - & $4.51 \pm 2.45^{\mathrm{Aa}}$ & $4.32 \pm 2.01^{\mathrm{Aa}}$ & $5.27 \pm 1.89^{\mathrm{Aa}}$ & $7.45 \pm 1.62^{\mathrm{Aa}}$ & $4.61 \pm 1.63^{\mathrm{Aa}}$ \\
\hline \multirow[t]{4}{*}{$\mathrm{pH}$} & $\mathrm{C}$ & $6.22 \pm 0.01^{\mathrm{Ac}}$ & $6.26 \pm 0^{\mathrm{Be}}$ & $6.24 \pm 0.01^{\mathrm{Bd}}$ & $6.24 \pm 0.01^{\mathrm{Bd}}$ & $5.98 \pm 0.01^{\mathrm{Ab}}$ & $5.71 \pm 0.01^{\mathrm{Aa}}$ \\
\hline & PS & $6.26 \pm 0^{\mathrm{Bd}}$ & $6.25 \pm 0.01^{\mathrm{Bd}}$ & $6.22 \pm 0.01^{\mathrm{ABcd}}$ & $6.19 \pm 0.03^{\mathrm{Ac}}$ & $6.09 \pm 0.04^{\mathrm{Bb}}$ & $5.92 \pm 0.04^{\mathrm{Ba}}$ \\
\hline & RE25 & $6.27 \pm 0.01^{\mathrm{Be}}$ & $6.26 \pm 0^{\text {Bde }}$ & $6.21 \pm 0.01^{\mathrm{Acd}}$ & $6.17 \pm 0.02^{\mathrm{Ac}}$ & $5.98 \pm 0.05^{\mathrm{Ab}}$ & $5.97 \pm 0.05^{\mathrm{Ba}}$ \\
\hline & RE50 & $6.28 \pm 0^{\mathrm{Cc}}$ & $6.24 \pm 0.01^{\mathrm{Abc}}$ & $6.21 \pm 0.01^{\mathrm{Abc}}$ & $6.16 \pm 0.03^{\mathrm{Ab}}$ & $6.03 \pm 0.06^{\mathrm{ABa}}$ & $5.90 \pm 0.09^{\mathrm{Ba}}$ \\
\hline
\end{tabular}

Values are given as mean \pm standard deviation. Different lowercase letters in the same row indicate significant difference during storage while different uppercase letters in the same column indicate significant difference among samples separately for each parameter $(\mathrm{P}<0.05)$.

afterwards. In case of coated samples, the pH constantly dropped during the storage. This is most likely due to the increase in concentration of organic acids because of the microbial and enzymatic activity. Enzymes from microorganisms that metabolize compounds in meat products will overhaul carbohydrates into lactic and acetic acid, which decreases the $\mathrm{pH}$ (Reynaldi et al., 2019). Microorganisms on meatballs may be originated from the surrounding environment, processing equipment and ingredients used in the formulation. Although the decreases in $\mathrm{pH}$ value were statistically insignificant $(\mathrm{P}>0.05)$, RE50 showed the most limited change in $\mathrm{pH}$ with an average value of 5.97 at the end of storage compared to other coated samples. This may be associated with the high antioxidant capability of rosemary extract used in the coating formulation.

In previous studies, Reynaldi et al. (2019) examined the effect of garlic extract, which is added to a gelatin-based edible coating to preserve the meatballs and extend their shelf life. They observed that $\mathrm{pH}$ value of the coated samples was higher ( $\mathrm{pH}$ 7.0-7.2 range) compared to the uncoated control while edible coatings prevented increase in the acidity. Pakpahan et al. (2019) investigated some of the quality parameters of meatballs coated by oleoresin-based coating. They determined that $\mathrm{pH}$ of uncoated control varied between 5.28 and 6.26 while $\mathrm{pH}$ of coated samples varied between 5.90 and 6.28 and $\mathrm{pH}$ varied significantly among the samples $(\mathrm{P}<0.05)$. Vital et al. (2018) examined the effect of an alginate-based edible coating containing natural antioxidants (rosemary and oregano essential oils) on beef stored for 14 days. In this context, some of its physical and chemical properties were checked during storage. It was concluded that there was no significant difference in $\mathrm{pH}$ values between the coated samples $(\mathrm{P}>0.05)$, but the $\mathrm{pH}$ was slightly higher in the control. Compared to Vital et al. (2018), in our study, it was determined that the $\mathrm{pH}$ value of the control is higher than the coated samples after 10 days of storage. In addition, it can be said that the $\mathrm{pH}$ value of the samples coated with rosemary in our study is higher than the $\mathrm{pH}$ value reported by Vital et al. (2018) at the end of the 7 th day. This may be due to the concentration of rosemary in the coatings.

The color characteristics of meat and meat products increase the visual preference of the products. Color characteristics increase the attractiveness of foods and affect consumer choice (Kılınççeker, 2013). Changes in L, a, b and $\Delta \mathrm{E}$ values of meatball samples during storage are given in Table 1 . While the $\mathrm{L}$ value significantly indicates the brightness in all samples, the differences between samples are insignificant $(\mathrm{P}>0.05)$. In other samples, the $\mathrm{L}$ value decreased during storage, while the L value of the control sample increased at the end of storage. The positive a value indicating mild redness showed a statistically significant increase during cold storage $(\mathrm{P}<0.05)$. Also, at the end of storage (10th day), differences between samples were found to be significant $(\mathrm{P}<0.05)$. The positive $\mathrm{b}$ value indicating mild yellowness increased during storage, but this increase and the differences between samples were statistically insignificant ( $P>0.05)$. Changes occurred in $\Delta \mathrm{E}$ value during storage. The color difference between the samples was compared with the samples analyzed on day 0 . Visible color differences are detected in the coated meatballs and these differences continued during storage. Statistically significant fluctuations were found in the color difference between samples during storage $(\mathrm{P}<0.05)$. In color measurement, $\Delta \mathrm{E}$ value indicates the color difference. If the $\Delta \mathrm{E}$ value is greater than 2.3 , there is a noticeable color difference. Looking at the results, it is seen that there is a noticeable color change in all samples. The color difference $(\Delta \mathrm{E})$ given in Table 1 was calculated for a better evaluation of the color change in the 
samples. When the results were evaluated, the $\Delta \mathrm{E}$ value decreased significantly $(\mathrm{P}<0.05)$ until the 7 th day with the effect of potassium sorbate in the PS sample, but it peaked again on the 10th day. However, changes in $\triangle \mathrm{E}$ value of other coated samples (samples RE25 and RE50) were not found to be significant $(\mathrm{P}>0.05)$. This indicates that all coating processes are successful in limiting the color change of meatballs during storage. In his study, Gerçek (2012) investigated the effect of coating with gelatin containing laurel and thyme oil on the quality of fish fillets stored at $+4{ }^{\circ} \mathrm{C}$ for 15 days, and concluded that it has a positive effect on the color values. Antoniewski et al. (2007) investigated the effect of salmon fillets on shelf life by coating them with gelatin. It was concluded that the gelatin coating acts as a barrier to oxygen passage during storage, preventing the decrease in color quality of the fillets.

\subsection{Free fatty acids}

Free fatty acid content is a measure of quality deterioration of meat products and it is produced due to bacterial enzymatic lipolysis through the breakdown of fat into fatty acids and triglycerides (Khare et al., 2016). Changes in FFA amount during storage are given in Table 2. If it is necessary to make a general evaluation for the analysis results, the FFA amount of all samples increased during the storage period and these increases were found to be statistically significant $(\mathrm{P}<0.05)$. Similar to the change in color difference $(\Delta E)$ of sample PS, the amount of FFA remained lower than the other samples until the 7th day, and peaked on the 10th day. Accordingly, it was determined that the FFA amount of the PS sample was lower until the 7th day compared to the control group, and the coating had a slight effect. Although statistically significant differences were observed between the groups during the entire storage period $(\mathrm{P}<0.05)$, it was found that the control group had a lower FFA amount on the 10th day and the coating did not have a significant effect on FFA.

Khare et al. (2016) observed changes in the quality parameters of chicken meat nuggets samples, on which cinnamon oil and chitosan enriched coatings were applied, during storage. The results showed that the FFA content increased significantly during storage and there was no significant difference between applications. In the study conducted by Gerçek (2012), it was determined that the samples coated with gelatin by adding laurel and thyme oil showed lower total volatile basic nitrogen, peroxide and free fatty acid values. Noor et al. (2018) investigated the effect of bioactive edible film containing Asparagus racemosus, which has antioxidant and antimicrobial effects, on meat quality. In edible films with antioxidant and antioxidant effects, lower FFA content was observed in all storage intervals compared to the control. Similarly, in our study, it was found that the amount of FFA in the coated samples remained lower until the 7th day. However, on the 10th day, the amount of FFA increased compared to the control. This may indicate that the effect of the coating on the samples is about 7 days.

\subsection{Thiobarbituric acid reactive substances}

Microbial spoilage along with chemical deterioration especially lipid oxidation is considered as one of the main factors limiting the shelf life of muscle foods (Khare et al., 2016). Lipid peroxidation was measured in terms of thiobarbituric acid (TBA) and was given in Table 2. It has been observed that TBA value increases and decreases during storage. When the results were compared, statistical differences were found between the samples $(\mathrm{P}<0.05)$, but these differences were not positively realized. The TBA value of group PS progressed at lower levels on the 10th day compared to the control. However, other groups in which the coating application was applied reached higher TBA values during storage compared to the control group.

In the study conducted by Song et al. (2011), the effect of edible coating containing different antioxidants on the quality and shelf life of cooled sea bream fish (Megalobrama amblycephala) was investigated. It was observed that the TBA values of all samples increased continuously during storage. However, it was determined that the TBA value of the uncoated samples was significantly lower $(\mathrm{P}<0.05)$. This showed that the coating containing antioxidant effectively prevents lipid oxidation. The study by Ruan et al. (2019) investigated the effect of edible coating on fresh pork quality and shelf life. TBA values of samples were measured as lipid oxidation index and it was determined that it increased continuously during storage. Compared to the uncoated

Table 2. Changes in the content of FFAs, TBARS and TVB-N during storage.

\begin{tabular}{|c|c|c|c|c|c|c|c|}
\hline Parameter & Sample & Initial & Day 1 & Day 2 & Day 3 & Day 7 & Day 10 \\
\hline \multirow[t]{4}{*}{ FFAs } & C & $0.90 \pm 0.10^{\mathrm{Aa}}$ & $0.97 \pm 0.04^{\mathrm{Aa}}$ & $1.23 \pm 0.06^{\mathrm{Ab}}$ & $1.24 \pm 0.20^{\mathrm{Ab}}$ & $1.52 \pm 0.13^{\mathrm{Bc}}$ & $1.43 \pm 0.10^{\mathrm{Abc}}$ \\
\hline & PS & $0.95 \pm 0.05^{\mathrm{Aa}}$ & $1.18 \pm 0.09^{\mathrm{Bb}}$ & $1.28 \pm 0.03^{\mathrm{Abc}}$ & $1.42 \pm 0.07^{\mathrm{Ac}}$ & $1.32 \pm 0.10^{\mathrm{Abc}}$ & $1.62 \pm 0.11^{\mathrm{Ad}}$ \\
\hline & RE25 & $0.97 \pm 0.06^{\mathrm{Aa}}$ & $1.14 \pm 0.02^{\mathrm{Bb}}$ & $1.28 \pm 0.04^{\mathrm{Ac}}$ & $1.26 \pm 0.06^{\mathrm{Abc}}$ & $1.37 \pm 0.06^{\mathrm{ABc}}$ & $1.66 \pm 0.14^{\mathrm{Ad}}$ \\
\hline & RE50 & $1.00 \pm 0.04^{\mathrm{Aa}}$ & $1.18 \pm 0.02^{\mathrm{Bb}}$ & $1.23 \pm 0.08^{\mathrm{Ab}}$ & $1.23 \pm 0.06^{\mathrm{Ac}}$ & $1.49 \pm 0.06^{\mathrm{Bcd}}$ & $1.60 \pm 0.12^{\mathrm{Ad}}$ \\
\hline \multirow[t]{4}{*}{ TBARS } & C & $0.30 \pm 0.01^{\text {Ade }}$ & $0.32 \pm 0.01^{\mathrm{Ae}}$ & $0.26 \pm 0.03^{\mathrm{Ac}}$ & $0.22 \pm 0.03^{\mathrm{Ab}}$ & $0.12 \pm 0.02^{\mathrm{Aa}}$ & $0.29 \pm 0.01^{\mathrm{Bd}}$ \\
\hline & PS & $0.37 \pm 0.01^{\mathrm{Bb}}$ & $1.09 \pm 0.10^{\mathrm{Cc}}$ & $0.31 \pm 0^{\mathrm{Aab}}$ & $0.28 \pm 0^{\mathrm{ABab}}$ & $0.28 \pm 0.12^{\mathrm{Aa}}$ & $0.26 \pm 0.01^{\mathrm{Aab}}$ \\
\hline & RE25 & $0.38 \pm 0.01^{\mathrm{Bc}}$ & $0.66 \pm 0.01^{\mathrm{Bd}}$ & $0.66 \pm 0.02^{\mathrm{Bb}}$ & $0.29 \pm 0.02^{\mathrm{Cb}}$ & $0.16 \pm 0.03^{\mathrm{Aa}}$ & $0.36 \pm 0.01^{\mathrm{Cc}}$ \\
\hline & RE50 & $0.37 \pm 0.01^{\mathrm{Bc}}$ & $0.31 \pm 0^{\mathrm{Ab}}$ & $0.31 \pm 0.06^{\mathrm{Ab}}$ & $0.38 \pm 0.06^{\mathrm{Dc}}$ & $0.19 \pm 0.01^{\mathrm{Aa}}$ & $0.36 \pm 0^{\mathrm{Cbc}}$ \\
\hline \multirow[t]{4}{*}{ TVB-N } & C & $16.53 \pm 0.94^{\mathrm{Aa}}$ & $17.56 \pm 1.42^{\mathrm{Aa}}$ & $21.78 \pm 1.70^{\mathrm{Ab}}$ & $20.84 \pm 1.31^{\mathrm{Ab}}$ & $21.08 \pm 1.17^{\mathrm{Ab}}$ & $19.48 \pm 1.04^{\mathrm{Aab}}$ \\
\hline & PS & $17.72 \pm 0^{\mathrm{ABa}}$ & $18.47 \pm 0^{\mathrm{ABab}}$ & $21.20 \pm 1.08^{\mathrm{Abc}}$ & $23.27 \pm 1.13^{\mathrm{Ac}}$ & $21.31 \pm 1.21^{\mathrm{Abc}}$ & $21.24 \pm 1.21^{\mathrm{ABb} C}$ \\
\hline & RE25 & $19.07 \pm 0.81^{\mathrm{Ca}}$ & $20.84 \pm 0^{\mathrm{ABab}}$ & $21.30 \pm 0.47^{\mathrm{Aab}}$ & $21.33 \pm 1.42^{\text {Aab }}$ & $22.10 \pm 1.57^{\mathrm{Ab}}$ & $21.16 \pm 0.81^{\mathrm{ABab}}$ \\
\hline & RE50 & $21.19 \pm 0.95^{\mathrm{Da}}$ & $20.45 \pm 1.24^{\mathrm{Ba}}$ & $22.16 \pm 0.77^{\mathrm{Aa}}$ & $22.64 \pm 1.02^{\mathrm{Aa}}$ & $21.52 \pm 1.68^{\mathrm{Aa}}$ & $22.89 \pm 1.04^{\mathrm{Ba}}$ \\
\hline
\end{tabular}

Values are given as mean \pm standard deviation. Different lowercase letters in the same row indicate significant difference during storage while different uppercase letters in the same column indicate significant difference among samples separately for each parameter $(\mathrm{P}<0.05)$. 
samples, it was found that the TBA values of the coated samples decreased significantly during storage $(\mathrm{P}<0.05)$. In our study, it was determined that the TBA value of the PS sample at the end of storage was lower than the control. This may be due to the antimicrobial effect of potassium sorbate.

\subsection{Total volatile basic nitrogen}

Meat freshness is very important for acceptance by end-consumers. However, the widespread adoption of TVB-N for interpretation of freshness is more limited in meats than in seafood. TVB-N is produced by the degradation of proteins and amines. The pathways of its formation are related to the activity of endogenous enzymes and disrupting bacteria on methylated amines. As a result, TVB-N content generally increases with meat products storage times, and this increase is consistent with other degradation biomarkers (Bekhit et al., 2021). When the results determined by us are examined, TVB-N values increased with the progress of storage and these increases occurred regularly on some days and irregularly on some days. These increases were found to be statistically significant $(\mathrm{P}<0.05)$. While the TVB-N value of the control group progressed at lower levels, the coated samples were found to have higher levels of TVB-N compared to the control.

In the study conducted by Andevari \& Rezaei (2011), the effect of coating with cinnamon oil containing gelatin on quality during storage of trout fillet in refrigerator conditions $\left(4 \pm 1^{\circ} \mathrm{C}\right)$ for 20 days was investigated. In the study, it was observed that gelatin films containing cinnamon oil decreased the TVB-N level. Kim et al. (2018) investigated the effect of edible antimicrobial coating on extending the shelf life of shrimp (Litopenaeus vannamei) stored at $4{ }^{\circ} \mathrm{C}$. The measured TVB-N value as an indicator of decay increased significantly during storage in all uncoated and coated samples $(\mathrm{P}<0.05)$. However, the increase in the amount of TVB-N in the samples coated with antimicrobial film was found to be rather limited compared to the control. TVBN value was observed during storage in the study conducted by Ruan et al. (2019) in which the effect of edible coating on pork quality was investigated. TVBN value increased during storage, but it was determined that this increase was limited in coated samples. The coating is thought to act as an oxygen barrier on samples, restricting oxidation and protein degradation caused by microorganisms.

\subsection{Textural features}

TPA results are given in Table 3. It is seen that hardness was lower in all coated samples at the end of the 10th day of storage compared to that of the control. Apparently, the coatings showed a softening effect. Cohesiveness was the highest in the control and the lowest in the PS sample although these differences were not statistically significant $(\mathrm{P}>0.05)$. The adhesiveness value of all coated samples is very low compared to the control. The lowest adhesiveness value was determined in the PS25 sample. The

Table 3. Textural properties of the samples.

\begin{tabular}{|c|c|c|c|c|c|c|c|}
\hline & Sample & Initial & Day 1 & Day 2 & Day 3 & Day 7 & Day 10 \\
\hline \multirow{4}{*}{ 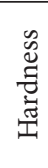 } & C & $701.96 \pm 54.74^{\mathrm{Ab}}$ & $612.43 \pm 74.72^{\mathrm{Ab}}$ & $697.60 \pm 135.80^{\mathrm{Aa}}$ & $815.77 \pm 110.05^{\mathrm{ABa}}$ & $1098.67 \pm 79.52^{\mathrm{Ca}}$ & $993.76 \pm 299.98^{\mathrm{BCa}}$ \\
\hline & PS & $641.30 \pm 43.23^{\mathrm{Aab}}$ & $633.46 \pm 20.57^{\mathrm{Ab}}$ & $576.63 \pm 38.01^{\mathrm{Aa}}$ & $603.53 \pm 30.29^{\mathrm{Aa}}$ & $1150.95 \pm 399.44^{\mathrm{Ba}}$ & $744.68 \pm 44.05^{\mathrm{Aa}}$ \\
\hline & RE25 & $587.22 \pm 44.47^{\mathrm{Ba}}$ & $457.87 \pm 8.37^{\mathrm{Aa}}$ & $746.33 \pm 80.52^{\mathrm{Ca}}$ & $664.34 \pm 48.45^{\mathrm{BCa}}$ & $870.45 \pm 40.78^{\mathrm{Da}}$ & $674.74 \pm 54.70^{\mathrm{BCa}}$ \\
\hline & RE50 & $718.48 \pm 70.42^{\mathrm{Ab}}$ & $619.62 \pm 120.32^{\mathrm{Ab}}$ & $580.32 \pm 100.65^{\mathrm{Aa}}$ & $849.76 \pm 235.49^{\text {Aa }}$ & $724.50 \pm 135.85^{\text {Аa }}$ & $695.16 \pm 138.20^{\mathrm{Aa}}$ \\
\hline \multirow{4}{*}{ 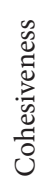 } & $\mathrm{C}$ & $0.50 \pm 0.01^{\mathrm{Aa}}$ & $0.57 \pm 0.07^{\mathrm{Aa}}$ & $0.73 \pm 0.37^{\mathrm{Aa}}$ & $0.50 \pm 0.01^{\mathrm{Aa}}$ & $0.47 \pm 0.02^{\mathrm{Aa}}$ & $0.87 \pm 0.40^{\mathrm{Aa}}$ \\
\hline & PS & $0.59 \pm 0.05^{\mathrm{Aab}}$ & $0.57 \pm 0.01^{\mathrm{Aa}}$ & $0.59 \pm 0.00^{\mathrm{Aa}}$ & $0.53 \pm 0.06^{\mathrm{Aa}}$ & $0.52 \pm 0.05^{\mathrm{Aab}}$ & $0.54 \pm 0.01^{\mathrm{Aa}}$ \\
\hline & RE25 & $0.65 \pm 0.08^{\mathrm{ABb}}$ & $0.66 \pm 0.04^{\mathrm{Aba}}$ & $0.73 \pm 0.18^{\mathrm{Ba}}$ & $0.60 \pm 0.07^{\mathrm{ABa}}$ & $0.55 \pm 0.05^{\mathrm{Ab}}$ & $0.57 \pm 0.02^{\mathrm{ABa}}$ \\
\hline & RE50 & $0.60 \pm 0.01^{\mathrm{Aab}}$ & $0.77 \pm 0.31^{\mathrm{Aa}}$ & $0.62 \pm 0.02^{\mathrm{Aa}}$ & $0.59 \pm 0.04^{\mathrm{Aa}}$ & $0.60 \pm 0.03^{\mathrm{Ab}}$ & $0.63 \pm 0.02^{\mathrm{Aa}}$ \\
\hline \multirow{4}{*}{ 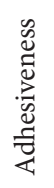 } & $\mathrm{C}$ & $-134.45 \pm 7.95^{\mathrm{Aa}}$ & $-399.74 \pm 110.85^{\mathrm{Ba}}$ & $-426.94 \pm 52.75^{\mathrm{Bb}}$ & $-346.43 \pm 2.66^{\mathrm{BC}}$ & $-309.18 \pm 3.84^{\mathrm{Bb}}$ & $-627.15 \pm 89.47^{\mathrm{Cd}}$ \\
\hline & PS & $-144.53 \pm 25.66^{\mathrm{Aa}}$ & $-406.57 \pm 4.57^{\mathrm{Ea}}$ & $-353.04 \pm 19.05^{\mathrm{Db}}$ & $-277.96 \pm 3.82^{\mathrm{Bb}}$ & $-288.16 \pm 1.53^{\mathrm{Bb}}$ & $-317.53 \pm 13.87^{\mathrm{cb}}$ \\
\hline & RE25 & $-311.02 \pm 9.29^{\mathrm{Cb}}$ & $-401.45 \pm 20.76^{\mathrm{Da}}$ & $-251.08 \pm 38.73^{\mathrm{Ba}}$ & $-133.84 \pm 41.36^{\mathrm{Aa}}$ & $-137.97 \pm 15.93^{\mathrm{Aa}}$ & $-132.22 \pm 5.90^{\mathrm{Aa}}$ \\
\hline & RE50 & $-352.55 \pm 34.99^{\mathrm{BCb}}$ & $-399.04 \pm 27.30^{\mathrm{BCa}}$ & $-174.96 \pm 69.37^{\mathrm{Aa}}$ & $-264.37 \pm 22.33^{\mathrm{ABb}}$ & $-331.81 \pm 154.24^{\mathrm{BCb}}$ & $-426.47 \pm 46.39^{C c}$ \\
\hline \multirow{4}{*}{ 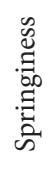 } & $\mathrm{C}$ & $0.54 \pm 0.01^{\mathrm{Aa}}$ & $0.60 \pm 0.08^{\mathrm{ABa}}$ & $0.57 \pm 0.04^{\mathrm{ABa}}$ & $0.58 \pm 0.01^{\mathrm{ABa}}$ & $0.55 \pm 0.01^{\mathrm{ABa}}$ & $0.62 \pm 0.02^{\mathrm{Bb}}$ \\
\hline & PS & $0.58 \pm 0.02^{\mathrm{Aba}}$ & $0.62 \pm 0.01^{\mathrm{Ba}}$ & $0.59 \pm 0.05^{\mathrm{ABa}}$ & $0.60 \pm 0.02^{\mathrm{Ba}}$ & $0.60 \pm 0.01^{\mathrm{Bb}}$ & $0.55 \pm 0.01^{\mathrm{Aa}}$ \\
\hline & RE25 & $0.75 \pm 0.02^{\mathrm{Dc}}$ & $0.69 \pm 0.03^{\mathrm{BCa}}$ & $0.73 \pm 0.03^{\mathrm{CDb}}$ & $0.62 \pm 0.03^{\mathrm{Aa}}$ & $0.65 \pm 0.01^{\mathrm{ABc}}$ & $0.68 \pm 0.03^{\mathrm{BCc}}$ \\
\hline & RE50 & $0.66 \pm 0.05^{\mathrm{ABb}}$ & $0.63 \pm 0.03^{\mathrm{ABa}}$ & $0.71 \pm 0.02^{\mathrm{Bb}}$ & $0.69 \pm 0.06^{\mathrm{Bb}}$ & $0.67 \pm 0.02^{\mathrm{ABc}}$ & $0.60 \pm 0.05^{\mathrm{Aab}}$ \\
\hline \multirow{4}{*}{ 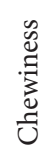 } & $\mathrm{C}$ & $190.11 \pm 10.24^{\mathrm{Aa}}$ & $212.44 \pm 57.42^{\mathrm{Aa}}$ & $282.06 \pm 123.85^{\mathrm{ABab}}$ & $236.49 \pm 28.29^{\mathrm{Aa}}$ & $286.46 \pm 37.61^{\mathrm{ABa}}$ & $589.09 \pm 35.67^{\mathrm{Ba}}$ \\
\hline & PS & $219.90 \pm 27.45^{\mathrm{Aa}}$ & $222.44 \pm 6.77^{\text {Аа }}$ & $199.35 \pm 21.26^{\mathrm{Aa}}$ & $195.00 \pm 31.53^{\mathrm{Aa}}$ & $357.03 \pm 100.1^{\mathrm{Ba}}$ & $219.34 \pm 17.70^{\mathrm{Aa}}$ \\
\hline & RE25 & $286.78 \pm 34.14^{\mathrm{Bb}}$ & $207.26 \pm 19.77^{\mathrm{Aa}}$ & $397.17 \pm 80.93^{\mathrm{cb}}$ & $245.69 \pm 28.78^{\mathrm{ABa}}$ & $315.08 \pm 26.96^{\mathrm{Ba}}$ & $261.05 \pm 24.54^{\mathrm{ABa}}$ \\
\hline & RE50 & $284.51 \pm 40.28^{\mathrm{Ab}}$ & $312.29 \pm 174.71^{\text {Aa }}$ & $252.41 \pm 43.72^{\mathrm{Aab}}$ & $335.28 \pm 51.99^{A b}$ & $287.86 \pm 32.77^{\mathrm{Aa}}$ & $263.21 \pm 25.52^{\mathrm{Aa}}$ \\
\hline \multirow{4}{*}{$\begin{array}{l}\mathscr{D} \\
\mathscr{\Xi} \\
\Xi \\
\Xi \\
\Xi \\
\Xi\end{array}$} & $\mathrm{C}$ & $349.63 \pm 22.43^{\mathrm{Aa}}$ & $350.52 \pm 55.79^{\mathrm{Aa}}$ & $491.22 \pm 199.25^{\mathrm{ABa}}$ & $408.85 \pm 53.48^{\mathrm{Aab}}$ & $518.05 \pm 57.13^{\mathrm{ABa}}$ & $942.11 \pm 60.51^{\mathrm{Ba}}$ \\
\hline & PS & $378.40 \pm 58.19^{\mathrm{Aa}}$ & $357.74 \pm 3.33^{\mathrm{Aa}}$ & $340.92 \pm 24.22^{\mathrm{Aa}}$ & $322.80 \pm 45.28^{\mathrm{Aa}}$ & $593.88 \pm 168.06^{\mathrm{Ba}}$ & $400.97 \pm 31.57^{\mathrm{Aa}}$ \\
\hline & RE25 & $382.50 \pm 53.62^{\mathrm{ABa}}$ & $301.51 \pm 21.55^{\mathrm{Aa}}$ & $542.05 \pm 104.81^{\mathrm{Ca}}$ & $398.57 \pm 54.01^{\mathrm{ABab}}$ & $482.38 \pm 41.97^{\mathrm{BCa}}$ & $382.16 \pm 29.32^{\mathrm{ABa}}$ \\
\hline & RE50 & $428.03 \pm 50.76^{\mathrm{Aa}}$ & $497.68 \pm 294.55^{\text {Aa }}$ & $356.24 \pm 51.34^{\mathrm{Aa}}$ & $491.10 \pm 110.47^{\mathrm{Ab}}$ & $430.30 \pm 59.42^{\mathrm{Aa}}$ & $439.73 \pm 77.28^{\mathrm{Aa}}$ \\
\hline
\end{tabular}

Values are given as mean \pm standard deviation. Different uppercase letters in the same row indicate significant difference during storage while different lowercase letters in the same column indicate significant difference among the samples separately for each parameter $(\mathrm{P}<0.05)$. 
differences observed in the adhesiveness values were found to be statistically significant $(\mathrm{P}<0.05)$. The highest spring rate was found in PS25 sample (0.68\%) and lowest in RE sample (0.55\%). The differences observed in springing values were also found to be statistically significant $(\mathrm{P}<0.05)$. At the end of storage, it was determined that the highest chewiness and gumminess values were in the control sample. The lowest chewiness was detected in the RE sample (219.34) and the lowest gumminess was detected in the PS25 sample (261.05). When evaluated in general, it was seen that the hardness, cohesiveness, adhesiveness, chewiness and gumminess values of the control sample were higher at the end of storage. It was found that the adhesiveness and springiness state were better in the coated samples. It was determined that the coating at the end of storage prevents the adhesiveness of the samples from increasing and retains the flexibility, especially in the RE sample.

Tosati et al. (2017) examined the effect of edible film, which is an antimicrobial agent carrier, on the textural properties of sausages. At the end of storage at $10{ }^{\circ} \mathrm{C}$ for 30 days, it was determined that the hardness and springiness values were higher in the uncoated sample, just as in our study. The cohesiveness value was almost the same in the coated and uncoated samples, while the chewiness value was significantly higher in the coated sample $(\mathrm{P}>0.05)$. In the study conducted by Gallego et al. (2020), the effect of gelatin coating enriched with antioxidant tomato by-products on pork quality was investigated. At the end of storage at $4{ }^{\circ} \mathrm{C}$ for 13 days, unlike our study, the hardness, cohesiveness and chewiness values were determined in the coated samples with the highest, elasticity in the best control and the highest adhesiveness values in the control, as in our study. In the study by Piedrahíta Márquez et al. (2019), fish fillets were treated with an edible coating enriched with antioxidant and antimicrobial substances. When the results of the TPA analysis performed at the end of 20 days of cold storage were examined, it was found that while adhesiveness increased, hardness and gumminess values decreased. At the end of storage, it was determined that the springiness was the highest in the coated samples, as in our study.

\section{Conclusions}

This study is among few studies on use of edible coatings for muscle foods. Although the results are not strongly conclusive, promising effects have been observed in terms of color preservation, suppressed protein deterioration and improved textural quality. Based on the results, it may be concluded that edible active coatings may help with the preservation of meatballs and extension of shelf life when applied properly in product-specific formulations. It was observed that coating with potassium sorbate (PS) showed a significant suppressive effect on TVB-N formation during storage. In addition, the coatings led to limited changes in $\mathrm{pH}$ values. Considering the TPA results, it was observed that hardness and stickiness were lower and the springiness was higher in coated samples compared to the control. It is, therefore, concluded that coating formulations studied resulted in improved textural quality. Significant differences were observed in color due to the color of coating itself but the coatings, in general, limited the variations in color to some extent. Further research is needed to determine proper formulation of edible coatings that may work for each group of food. In future research, different bioactive ingredients and/or functional compounds may be incorporated with various carrier polymers to develop effective edible coatings.

\section{References}

Aloui, H., \& Khwaldia, K. (2016). Natural antimicrobial edible coatings for microbial safety and food quality enhancement. Comprehensive Reviews in Food Science and Food Safety, 15(6), 1080-1103. http:// dx.doi.org/10.1111/1541-4337.12226. PMid:33401837.

American Oil Chemists Society - AOCS. (1989). Official methods and recommended practices of the American Oil Chemists Society (4th ed., Methods Ca 5a-40, Cd8-53, Ch 5-91). Urbana, IL: AOCS.

Andevari, G. T., \& Rezaei, M. (2011). Effect of gelatin coating incorporated with cinnamon oil on the quality of fresh rainbow trout in cold storage. International Journal of Food Science \& Technology, 46(11), 2305-2311. http://dx.doi.org/10.1111/j.1365-2621.2011.02750.x.

Antoniewski, M. N., Barringer, S. A., Knipe, C. L., \& Zerby, H. N. (2007). Effect of a gelatin coating on the shelf life of fresh meat. Journal of Food Science, 72(6), E382-E387. http://dx.doi.org/10.1111/j.17503841.2007.00430.x. PMid:17995684.

Bekhit, A. A., Holman, B. W. B., Giteru, S. G., \& Hopkins, D. L. (2021). Total volatile basic nitrogen (TVB-N) and its role in meat spoilage: a review. Trends in Food Science \& Technology, 109, 280-302. http:// dx.doi.org/10.1016/j.tifs.2021.01.006.

Bojorges, H., Ríos-Corripio, M. A., Hernández-Cázares, A. S., HidalgoContreras, J. V., \& Contreras-Oliva, A. (2020). Effect of the application of an edible film with turmeric (Curcuma longa L.) on the oxidative stability of meat Hylenne. Food Science \& Nutrition, 8(8), 4308-4319. http://dx.doi.org/10.1002/fsn3.1728. PMid:32884711.

Bolumar, T., Orlien, V., Sikes, A., Aganovic, K., Bak, K. H., Guyon, C., Stübler, A. S., de Lamballerie, M., Hertel, C., \& Brüggemann, D. A. (2021). High-pressure processing of meat: Molecular impacts and industrial applications. Comprehensive Reviews in Food Science and Food Safety, 20(1), 332-368. http://dx.doi.org/10.1111/15414337.12670. PMid:33443800.

Boran, G. (2011). Bir gıda katkısı olarak jelatin: yapısı, özellikleri, üretimi, kullanımı ve kalitesi. Gıda, 36(2), 97-104.

Bourne, M. (2002). Food texture and viscosity: concept and measurement (pp. 183-184). New York: Academic Press. http://dx.doi.org/10.1016/ B978-012119062-0/50001-2.

Bravin, B., Peressini, D., \& Sensidoni, A. (2006). 2015. Development and application of polysaccharide-lipid edible coating to extend shelf-life of dry bakery products. Journal of Food Engineering, 76(3), 280-290. http://dx.doi.org/10.1016/j.jfoodeng.2005.05.021.

Chinnaswamy, R., \& Hanna, M. A. (1988). Expansion, color and shear strength properties of corn starches extrusion-cooked with urea and salts. Stärke, 5(5), 186-190. http://dx.doi.org/10.1002/star.19880400507.

Choulitoudi, E., Ganiari, S., Tsironi, T., Ntzimani, A., Tsimogiannis, D., Taoukis, P., \& Oreopoulou, V. (2017). Edible coating enriched with rosemary extracts to enhance oxidative and microbial stability of smoked eel fillets. Food Packaging and Shelf Life, 12, 107-113. http:// dx.doi.org/10.1016/j.fpsl.2017.04.009.

Díaz-Montes, E., \& Castro-Muñoz, R. (2021). Edible films and coatings as food-quality preservers: an overview. Foods, 10(2), 249. PMid:33530469.

Duman, M., Çoban, E. Ö., \& Özpolat, E. (2012). Biberiye ve kekik esansiyel yağları katkısının marine edilmiş kerevitlerin (Astacus 
leptodactylus Esch., 1823) raf ömrüne etkisinin belirlenmesi. Kafkas Üniversitesi Veteriner Fakültesi Dergisi, 18(5), 745-751.

Fabra, M. J., Falcó, I., Randazzo, W., Sánchez, G., \& López-Rubio, A. (2018). Antiviral and antioxidant properties of active alginate edible films containing phenolic extracts. Food Hydrocolloids, 81, 96-103. http://dx.doi.org/10.1016/j.foodhyd.2018.02.026.

Gallego, M., Arnal, M., Talens, P., Toldrá, F., \& Mora, L. (2020). Effect of gelatin coating enriched with antioxidant tomato by-products on the quality of pork meat. Polymers, 12(5), 2-18. http://dx.doi. org/10.3390/polym12051032. PMid:32370120.

Gerçek, G. (2012). Defne ve kekik yağı eklenen jelatin ile kaplamanın çipura (Sparus aurata L., 1758) filetolarının soğukta $\left(+4^{\circ} \mathrm{C}\right)$ depolanması esnasında fiziksel, kimyasal, mikrobiyolojik ve duyusal değişimler üzerine etkisi (Master thesis). Çukurova University, Adana.

Ivanovic, S., Mikinac, K., \& Perman, L. (2011). Molecular gastronomy in function of scientific implementation in practice. UTMS Journal of Economics, 2(2), 139-150.

Kester, J. J., \& Fennema, O. (1989). An edible film of lipids and cellulose ethers: performance in a model frozen-food system. Journal of Food Science, 54(1406), 1390-1392. http://dx.doi.org/10.1111/j.1365-2621.1989. tb05119.x.

Khare, A. K., Abraham, R. J. J., Rao, V. A., Babu, R. N., \& Ruban, W. (2016). Effect of chitosan coating enriched with cinnamon oil (Cinnamomum zeylanicum) on storage stability of refrigerated chicken meat nuggets. Journal of Animal Research, 6(2), 1-14. http:// dx.doi.org/10.5958/2277-940X.2015.00160.6.

Kılınççeker, O. (2013). Utilization of oat flour as edible coating material on fried chicken meat balls. Focusing on Modern Food Industry, 2(1), 36-42.

Kim, J. H., Hong, W., \& Oh, S. W. (2018). Effect of layer-by-layer antimicrobial edible coating of alginate and chitosan with grape fruit seed extract for shelf-life extension of shrimp (Litopenaeus vannamei) stored at $4{ }^{\circ} \mathrm{C}$. International Journal of Biological Macromolecules, 120(Pt B), 1468-1473. http://dx.doi.org/10.1016/j. ijbiomac.2018.09.160. PMid:30267814.

Noor, S., Bhat, Z. F., Kumar, S., \& Mudiyanselage, J. R. (2018). Preservative effect of Asparagus racemosus: A novel additive for bioactive edible films for improved lipid oxidative stability and storage quality of meat products. Meat Science, 139(7), 207-212. http://dx.doi.org/10.1016/j. meatsci.2018.02.001. PMid:29459296.

Olgunoğlu, G. A. 2007. Marine edilmiş hamside (Engraulis engrasicholus L., 1758) duyusal, kimyasal ve mikrobiyolojik değişimler (Doktora tezi). Çukurova Üniversitesi, Adana.

Özdemir, G., \& Altıner, D. D. (2018). Gıda sanayinde kullanılan bazı katkı maddelerinin moleküler gastronomide uygulama alanları. In Bildiriler Kitabı Uluslararası Marmara Fen ve Sosyal Bilimler Kongresi-2018 (pp. 1157-1162). Türkiye.

Pakpahan, O. P., Anggita, C., Cahyanti, S., Putri, N. D., \& Monica, A. S. (2019). Performance edible coating containing oleoresin from ginger emprit (Zingiber offivinale var. amarum) and its effect on consumer preference properties. Carpathian Journal of Food Science and Technology, 11(3), 175-184.

Piedrahíta Márquez, D. G., Fuenmayor, C. A., \& Mahecha, H. S. (2019). Effect of chitosan-propolis edible coatings on stability of refrigerated cachama (Piaractus brachypomus) vacuum-packed fish fillets. Packaging Technology \& Science, 32(3), 143-153.

Pranoto, Y., Rakshit, S. K., \& Salokhe, V. M. (2005). 2004. Enhancing antimicrobial activity of chitosan films by incorporating garlic oil, potassium sorbate and nisin. LWT, 38(8), 859-865. http://dx.doi. org/10.1016/j.lwt.2004.09.014.

Reynaldi, A., Rostini, I., Afrianto, E., \& Rochima, E. (2019). The effect of garlic extract addition on tilapia skin gelatin based edible coating towards antimicrobial properties and fish meatball's shelf life. World Scientific News, 134(2), 74-85.

Ruan, C., Zhang, Y., Sun, Y., Gao, X., Xiong, G., \& Liang, J. (2019). Effect of sodium alginate and carboxymethyl cellulose edible coating with epigallocatechin gallate on quality and shelf life of fresh pork. International Journal of Biological Macromolecules, 141(15), 178-184. http://dx.doi.org/10.1016/j.ijbiomac.2019.08.247. PMid:31476396.

Shen, X. L., Wu, J. M., Chen, Y., \& Zhao, G. (2010). Antimicrobial and physical properties of sweet potato starch films incorporated with potassium sorbate or chitosan. Food Hydrocolloids, 24(4), 285-290. http://dx.doi.org/10.1016/j.foodhyd.2009.10.003.

Soares, N. M., Mendes, T. S., \& Vicente, A. A. (2013). Effect of chitosanbased solutions applied as edible coatings and water glazing on frozen salmon preservation. Journal of Food Engineering, 119(2), 316-323. http://dx.doi.org/10.1016/j.jfoodeng.2013.05.018.

Song, Y., Liu, L., Shen, H., You, J., \& Luo, Y. (2011). Effect of sodium alginate-based edible coating containing different anti-oxidants on quality and shelf life of refrigerated bream (Megalobrama amblycephala). Food Control, 22(3-4), 608-615. http://dx.doi. org/10.1016/j.foodcont.2010.10.012.

Tarladgis, B. G., Watts, B. M., Younathan, M. T., \& Dugan, L. Jr. (1960). Distillation method for the determination of malonaldehyde in rancid foods. Journal of the American Oil Chemists' Society, 37(1), 44-48. http://dx.doi.org/10.1007/BF02630824.

Topuz, C. F., \& Boran, G. (2018). Jelatin bazlı yenilebilir film ve kaplamalar. Akademik Gida, 16(3), 332-339.

Tosati, J. V., Messias, V. C., Carvalho, P. I. N., Rodrigues Pollonio, M. A., Meireles, M. A. A., \& Monteiro, A. R. (2017). Antimicrobial effect of edible coating blend based on turmeric starch residue and gelatin applied onto fresh frankfurter sausage. Food and Bioprocess Technology, 10(12), 2165-2175. http://dx.doi.org/10.1007/s11947017-1985-1.

Umaraw, P., Munekata, P. E. S., Verma, A. K., Barba, F. J., Singh, V. P., Kumar, P., \& Lorenzo, J. M. (2020). Edible films/coating with tailored properties for active packaging of meat, fish and derived products. Trends in Food Science \& Technology, 98, 10-24. http:// dx.doi.org/10.1016/j.tifs.2020.01.032.

Vital, A. C. P., Guerrero, A., de Oliveira Monteschio, J., Valero, M. V., Carvalho, C. B., Abreu, B. A. Fo., Madrona, G. S., \& Prado, I. N. (2016). Effect of edible and active coating (with rosemary and oregano essential oils) on beef characteristics and consumer acceptability. PLoS One, 18(11), 1-15. http://dx.doi.org/10.1371/ journal.pone.0160535. PMid:27504957.

Vital, A. C. P., Guerrero, A., Kempinski, E. M. B. C., Monteschio, J. D., Sary, C., Ramos, T. R., del Mar Campo, M., \& Prado, I. N. (2018). Consumer profile and acceptability of cooked beef steaks with edible and active coating containing oregano and rosemary essential oils. Meat Science, 143, 153-158. http://dx.doi.org/10.1016/j. meatsci.2018.04.035. PMid:29753217.

Xie, L., Hettiarachchy, N. S., Ju, Z. Y., Meullenet, J., Wang, H. M. F., Slavik, M. F., \& Janes, M. E. (2002). Edible film coating to minimize egg shell breakage and reduce post-wash bacterial contamination measured by dye penetration in eggs. Food and Chemical Toxicology, 67(1), 280-284. 